University of Nebraska - Lincoln

DigitalCommons@University of Nebraska - Lincoln

Publications from USDA-ARS / UNL Faculty

U.S. Department of Agriculture: Agricultural

Research Service, Lincoln, Nebraska

1999

Nuclear DNA Content of Perennial Grasses of the Triticeae

Kenneth P. Vogel

University of Nebraska-Lincoln, kvogel1@unl.edu

K. Arumuganathan

University of Nebraska-Lincoln

Kevin B. Jensen

USDA-ARS

Follow this and additional works at: https://digitalcommons.unl.edu/usdaarsfacpub

Vogel, Kenneth P.; Arumuganathan, K.; and Jensen, Kevin B., "Nuclear DNA Content of Perennial Grasses of the Triticeae" (1999). Publications from USDA-ARS / UNL Faculty. 1918.

https://digitalcommons.unl.edu/usdaarsfacpub/1918

This Article is brought to you for free and open access by the U.S. Department of Agriculture: Agricultural Research Service, Lincoln, Nebraska at DigitalCommons@University of Nebraska - Lincoln. It has been accepted for inclusion in Publications from USDA-ARS / UNL Faculty by an authorized administrator of DigitalCommons@University of Nebraska - Lincoln. 


\title{
Nuclear DNA Content of Perennial Grasses of the Triticeae
}

\author{
Kenneth P. Vogel,* K. Arumuganathan, and Kevin B. Jensen
}

\begin{abstract}
Nuclear DNA content was determined by flow cytometry for an array of perennial species of the Triticeae (Poaceae) which characterize the tribe and are representative of the genomes of the Triticeae. The mean nuclear DNA content expressed on a diploid basis (DNA $\mathrm{pg} / 2 \mathrm{C}$ ) for the diploid genomes (in parentheses) were as follows: Agropyron (PP) 13.9 pg, Pseudoroegneria (StSt) 8.8 pg, Hordeum (HH) 9.5 pg, Psathyrostachys (NsNs) $16.7 \mathrm{pg}$, and Thinopyrum genomes $\left(E^{b} E^{b}\right) 14.9 \mathrm{pg}$ and $\left(E^{e} E^{e}\right) 12.0 \mathrm{pg}$. The $Y Y$ genome in Elymus was determined by difference to be $9.3 \mathrm{pg}$. The unknown or $\mathrm{XmXm}$ genome or genomes in Leymus could have DNA contents that range from 2.7 to $7.7 \mathrm{pg} / 2 \mathrm{C}$. There were significant differences in DNA content of species with similar diploid genomes. There were also significant differences in nuclear DNA content among polyploid species with the same genomes. In general, the nuclear DNA content of the polyploid species of the Triticeae were similar to the expected DNA contents on the basis of previous genomic classifications. However, in some allopolyploid genera such as Thinopyrum and Pascopyrum, the nuclear DNA content of some species was less than expected on the basis of summation of the DNA of constituent genomes. The results indicate that gain or loss of nuclear DNA has occurred during the evolution of the perennial Triticeae and was probably a part of speciation.
\end{abstract}

K.P. Vogel, USDA-ARS, Wheat, Sorghum, and Forage Res. Unit, 344 Keim Hall, Univ. of Nebraska, P.O. Box 830937, Lincoln, NE 68507-0937; K. Arumuganathan, Center for Biotechnology, N322 Beadle Hall, Univ. of Nebraska, Lincoln, NE 68516; K.B. Jensen, USDAARS, Forage and Range Res. Lab., Utah State Univ., Logan, UT 84322-6300. Journal series no. 11956. Nebraska Agric. Exp. Stn. Received 31 Dec. 1997. *Corresponding author (agro012@unlvm.unl. edu.).

Published in Crop Sci. 39:661-667 (1999).
$\mathrm{P}$ REvious research summarized by Dewey (1984), Wang et al. (1994), and Asay and Jensen (1996a,b), and others has demonstrated that the perennial grasses of the tribe Triticeae are based on the P, St, H, Ns, E, $\mathrm{W}, \mathrm{Y}$ genomes and an unknown $\times$ genome(s). The cytogenetic definition of genome, i.e., the haploid set of chromosomes of a diploid species, will be used in this report. The classification of the Triticeae has been and remains a matter of controversy (Barkworth, 1992; Barkworth and Dewey, 1985; Kellogg, 1994). Barkworth (1992) and Kellogg (1994) agree that developing a classification system for the Triticeae has been and will remain difficult because of the complex evolutionary history of the tribe. For the purposes of this paper, the genomic classification described by Dewey (1984) and Barkworth and Dewey (1985) will be used with the following exceptions. Dewey (1984) indicated that Leymus species and Pascopyrum contain the $\mathrm{J}(=\mathrm{E})$ genome. Subsequent reports (Zhang and Dvorak, 1991; Wang and Jensen, 1994) based on molecular genetic and cytogenetic analyses indicate that the $J$ genome does not occur in Leymus or Pascopyrum. Asay and Jensen $(1996 a, b)$ have designated the unknown genome in Leymus and Pascopyrum the Xm or unknown genome following the genome nomenclature system for the Triticeae proposed by Wang et al. (1994). Species classified as Critesion by Barkworth and Dewey (1985) are listed as Hordeum in this report. The genome nomenclature system of Wang et al. (1994) will be used

Abbreviations: 2C, DNA content of a diploid nucleus; Da, daltons. 
Table 1. DNA content of species of perennial Triticeae.

\begin{tabular}{|c|c|c|c|c|c|c|}
\hline \multirow[b]{2}{*}{$\underline{\text { Species }}$} & \multirow[b]{2}{*}{ Genome $\dagger$} & \multirow[b]{2}{*}{$2 n$} & \multirow[b]{2}{*}{$\begin{array}{c}\text { Strain or } \\
\text { accession } \neq\end{array}$} & \multicolumn{3}{|c|}{ DNA pg/2C§ } \\
\hline & & & & Mean & SD & $\begin{array}{c}\text { Confidence } \\
\text { interval }(95 \%)\end{array}$ \\
\hline \multicolumn{7}{|l|}{ Agropyron Gaertner } \\
\hline $\begin{array}{l}\text { A. cristatum (L.) Gaertner } \\
\text { A. cristatum } \\
\text { A. cristatum } \\
\text { A. mongolicum Keng } \\
\text { A. mongolicum } \\
\text { A. desertorum (Fischer ex Link) Shultes } \\
\text { A. desertorum }\end{array}$ & $\begin{array}{l}\text { PP } \\
\text { PP } \\
\text { PP } \\
\text { PP } \\
\text { PP } \\
\text { PPPP } \\
\text { PPPP }\end{array}$ & $\begin{array}{l}14 \\
14 \\
14 \\
14 \\
14 \\
28 \\
28\end{array}$ & $\begin{array}{l}\text { PI } 297870 \\
\text { PI 314600 } \\
\text { cv Ruff } \\
\text { PI } 499391 \\
\text { PI } 499392 \\
\text { PI } 249143 \\
\text { cv Nordan }\end{array}$ & $\begin{array}{l}13.46 \\
14.25 \\
13.19 \\
15.57 \\
15.16 \\
26.39 \\
25.45\end{array}$ & $\begin{array}{l}0.06 \\
0.43 \\
0.16 \\
0.14 \\
0.58 \\
0.55 \\
0.49\end{array}$ & $\begin{array}{l}13.37-13.55 \\
13.57-14.93 \\
12.94-13.44 \\
15.35-15.58 \\
14.24-16.08 \\
25.51-27.27 \\
24.67-26.23\end{array}$ \\
\hline \multicolumn{7}{|l|}{ Pseudoroegneria (Nevski) À. Löve } \\
\hline $\begin{array}{l}\text { P. strigosa subsp. aegilopoides (Drobov.) À. Löve } \\
P \text {. strigosa (M. Bieb) } \\
P \text {. libanotica (Hackel) D.R. Dewey } \\
P \text {. libanotica } \\
P \text {. spicata (Pursh) À. Löve subsp. spicata } \\
P \text {. spicata } \\
P \text {. stipifolia (Czern ex Nevski) } \\
P . \text { geniculata (Trin.) À. Löve } \\
P . \text { geniculata }\end{array}$ & $\begin{array}{l}\text { StSt } \\
\text { StSt } \\
\text { StSt } \\
\text { StSt } \\
\text { StSt } \\
\text { StSt } \\
\text { StSt } \\
\text { StStStSt } \\
\text { StStStSt }\end{array}$ & $\begin{array}{l}14 \\
14 \\
14 \\
14 \\
14 \\
14 \\
14 \\
28 \\
28\end{array}$ & $\begin{array}{l}\text { PI } 531755 \\
\text { D3778 } \\
\text { PI 380644 } \\
\text { PI 380652 } \\
\text { PI 232127 } \\
\text { PI 232134 } \\
\text { PI 440000 } \\
\text { DJ3875 } \\
\text { DJ3882 }\end{array}$ & $\begin{array}{r}\mathbf{9 . 4 5} \\
\mathbf{9 . 7 2} \\
\mathbf{7 . 9 6} \\
\mathbf{7 . 8 5} \\
\mathbf{9 . 4 3} \\
\mathbf{9 . 0 9} \\
\mathbf{8 . 0 0} \\
\mathbf{1 6 . 9 6} \\
\mathbf{1 7 . 4 8}\end{array}$ & $\begin{array}{l}\mathbf{0 . 4 1} \\
0.43 \\
\mathbf{0 . 4 2} \\
\mathbf{0 . 2 9} \\
\mathbf{0 . 1 6} \\
\mathbf{0 . 4 9} \\
\mathbf{0 . 0 7} \\
\mathbf{0 . 2 7} \\
\mathbf{0 . 2 4}\end{array}$ & \begin{tabular}{|l|}
$8.79-10.11$ \\
$9.03-10.41$ \\
$7.29-8.64$ \\
$7.38-8.31$ \\
$9.16-9.69$ \\
$8.31-9.87$ \\
$7.88-8.11$ \\
$16.53-17.39$ \\
$17.11-17.86$
\end{tabular} \\
\hline \multicolumn{7}{|l|}{ Hordeum $\mathbf{L}}$. \\
\hline $\begin{array}{l}\text { H. bogdanii Wilensky } \\
\text { H. brachyantherum Nevski } \\
\text { H. brevisubulatum-violaceum (Boise \& Hofenacker) Tzvelev } \\
\text { H. bulbosum L. } \\
\text { H. bulbosum } \\
\text { H. califormicum Covas \& Stebbins } \\
\text { H. californicum } \\
\text { H. chilense Roemer \& Schultes } \\
\text {. comosum K. Presl } \\
H \text {. flexuosum Nees } \\
\text {. haplophilum Griseb. } \\
\text { H. roshevitzii Bowden } \\
H \text {. stenostachys Godron } \\
\text { H. stenostachys }\end{array}$ & $\begin{array}{l}\text { HH } \\
\text { HH } \\
\text { HH } \\
\text { HH } \\
\text { HHHH } \\
\text { HH } \\
\text { HH } \\
\text { HH } \\
\text { HH } \\
\text { HH } \\
\text { HH } \\
\text { HH } \\
\text { HH } \\
\text { HH }\end{array}$ & $\begin{array}{l}14 \\
14 \\
14 \\
14 \\
28 \\
14 \\
14 \\
14 \\
14 \\
14 \\
14 \\
14 \\
14\end{array}$ & $\begin{array}{l}\text { PI } 440413 \\
\text { D3571 } \\
\text { PI 401374 } \\
\text { PI } 318649 \\
\text { PI } 343189 \\
\text { PI 531778 } \\
\text { PI 531799 } \\
\text { PI 531781 } \\
\text { D2742 } \\
\text { cv Castelar } 730 \\
\text { D2749 } \\
\text { PI 499504 } \\
\text { PI } 531791 \\
\text { PI } 531792\end{array}$ & \begin{tabular}{|r|}
9.47 \\
9.67 \\
9.93 \\
9.16 \\
17.74 \\
9.52 \\
9.52 \\
9.90 \\
9.27 \\
8.86 \\
8.85 \\
10.12 \\
10.04 \\
10.05
\end{tabular} & $\begin{array}{l}0.14 \\
0.05 \\
0.20 \\
0.13 \\
0.24 \\
0.06 \\
0.25 \\
0.45 \\
0.05 \\
0.16 \\
0.32 \\
0.42 \\
0.20 \\
0.26\end{array}$ & $\begin{array}{c}9.25-9.69 \\
9.58-9.75 \\
9.61-10.24 \\
\mathbf{8 . 9 6 - 9 . 3 6} \\
\mathbf{1 7 . 3 6 - 1 8 . 1 3} \\
\mathbf{9 . 4 3 - 9 . 6 1} \\
\mathbf{9 . 1 2 - 9 . 9 2} \\
\mathbf{9 . 1 8 - 1 0 . 6 2} \\
\mathbf{9 . 1 9 - 9 . 3 5} \\
\mathbf{8 . 6 1 - 9 . 1 1} \\
\mathbf{8 . 3 4 - 9 . 3 7} \\
\mathbf{9 . 4 5 - 1 0 . 7 9} \\
\mathbf{9 . 7 2 - 1 0 . 3 5} \\
\mathbf{9 . 6 3 - 1 0 . 4 6}\end{array}$ \\
\hline \multicolumn{7}{|l|}{ Psathyrostachys Nevski } \\
\hline $\begin{array}{l}P . \text { fragilis (Boise) Nevski } \\
P . \text { juncea (Fisher) Nevski } \\
P . \text { juncea } \\
P . \text { stoloniformis C. Baden } \\
P . \text { stoloniformis }\end{array}$ & $\begin{array}{l}\text { NsNs } \\
\text { NsNs } \\
\text { NsNs } \\
\text { NsNs } \\
\text { NsNs }\end{array}$ & $\begin{array}{l}14 \\
14 \\
14 \\
14 \\
14\end{array}$ & $\begin{array}{l}\text { PI } 343190 \\
\text { PI } 406468 \\
\text { PI } 531824 \\
\text { D2562 } \\
\text { D3376 }\end{array}$ & $\begin{array}{l}16.79 \\
15.60 \\
15.53 \\
17.85 \\
17.91\end{array}$ & $\begin{array}{l}0.32 \\
0.15 \\
0.22 \\
0.74 \\
0.14\end{array}$ & $\begin{array}{l}16.29-17.30 \\
15.37-15.83 \\
15.18-15.88 \\
16.67-19.02 \\
17.69-18.12\end{array}$ \\
\hline \multicolumn{7}{|l|}{ Thinipyrum À. Löve } \\
\hline $\begin{array}{l}\text { T. bessarabicum (Savul \& Rayass) À. Löve } \\
\text { T. bessarabicum } \\
T . \text { elongatum (Host) D.R. Dewey } \\
T . \text { elongatum } \\
T . \text { junceiforme (Löve \& Löve) À. Löve } \\
T . \text { junceiforme } \\
T . \text { caespitosum Liu \& Wang } \\
T . \text { intermedium subsp. intermedium (Host) Barkw. \& D.R. Dewey } \\
T . \text { intermedium subsp. barbulatum (Shur) Barkw. \& D.R. Dewey } \\
T . \text { ponticum (Podp.) Barkw. \& D.R. Dewey }\end{array}$ & $\begin{array}{l}\mathbf{E}^{\mathrm{b}} \mathbf{E}^{\mathbf{b}} \\
\mathbf{E}^{\mathrm{b}} \mathbf{E}^{\mathrm{b}} \\
\mathbf{E}^{\mathrm{e}} \mathbf{E}^{\mathrm{e}} \\
\mathbf{E}^{\mathbf{e} \mathbf{E}^{\mathbf{e}}} \\
\mathbf{E E E E} \\
\text { EEEE } \\
\text { EEStSt } \\
\text { EEEEStSt } \\
\text { EEEEStSt } \\
\text { EEEEEEStStStSt }\end{array}$ & $\begin{array}{l}14 \\
14 \\
14 \\
14 \\
28 \\
28 \\
28 \\
42 \\
42 \\
70\end{array}$ & $\begin{array}{l}\text { PI } 431711 \\
\text { AJC305 } \\
\text { PI } 531719 \\
\text { D3610 } \\
\text { PI } 297873 \\
\text { D3463 } \\
\text { PI } 531716 \\
\text { cv Slate } \\
\text { cv Manska } \\
\text { cv Platte }\end{array}$ & $\begin{array}{l}14.87 \\
14.96 \\
11.74 \\
12.20 \\
25.97 \\
23.62 \\
19.88 \\
26.25 \\
25.92 \\
45.26\end{array}$ & $\begin{array}{l}0.25 \\
0.42 \\
0.14 \\
0.23 \\
0.40 \\
0.32 \\
1.12 \\
0.62 \\
0.47 \\
1.49\end{array}$ & $\begin{array}{l}14.47-15.27 \\
14.30-15.62 \\
11.51-11.97 \\
11.84-12.56 \\
25.33-26.60 \\
23.12-24.13 \\
18.09-21.67 \\
25.25-27.24 \\
25.17-26.68 \\
42.89-47.64\end{array}$ \\
\hline
\end{tabular}

Table 1 continued next page.

in this report; hence, the J genome will be subsequently referred to as the $\mathrm{E}$ genome.

The base DNA content of the genomes of the perennial Triticeae has previously not been determined, except for initial reports on the $\mathrm{H}$ and $\mathrm{E}$ genomes (Bennett and Smith, 1976). Bennett and Smith (1991) described the utility of nuclear DNA content values in phlyogenetic and evolutionary studies. Applications include determining if DNA content increases in proportion to ploidy levels and if the DNA content of allopolyploids equals the sum of the DNA content of genomes of donor species. To avoid confusion with chromosome number, DNA amounts are expressed in picograms as "C" values (Bennett and Leitch, 1995; Bennett and Smith, 1976). The letter C stands for "constant" or the amount of
DNA in a haploid nucleus or haploid genome; $2 \mathrm{C}$ values, which are reported in this paper, represent the DNA content of a diploid somatic nucleus. DNA amounts in picograms can be approximately converted to daltons or nucleotide pairs by the formulas: 1 nucleotide pair $=660 \mathrm{Da} ; 1 \mathrm{pg}=0.965 \times 10^{9}$ nucleotide pairs $($ Bennett and Smith, 1976). For the few species of the perennial Triticeae determined to date, the DNA content as determined by in situ microphotodensitometry of somatic root tips was as follows: Hordeum bulbosum, $2 n=14$, $11.0 \mathrm{pg} / 2 \mathrm{C}$ (H genome); Hordeum bulbosum, $2 n=28$, $22.1 \mathrm{pg} / 2 \mathrm{C}$; and Thinopyrum elongatum ( $\mathrm{E}^{\mathrm{e}}$ genome), $2 n=14,11.2 \mathrm{pg} / 2 \mathrm{C}$ (Bennett and Smith, 1976).

Determination of DNA content by microphotodensitometry is laborious and time consuming (Michaelson 
Table 1. continued.

\begin{tabular}{|c|c|c|c|c|c|c|}
\hline \multirow[b]{2}{*}{ Species } & \multirow[b]{2}{*}{ Genome $\dagger$} & \multirow[b]{2}{*}{$2 n$} & \multirow[b]{2}{*}{$\begin{array}{c}\text { Strain or } \\
\text { accession } \neq\end{array}$} & \multicolumn{3}{|c|}{ DNA pg/2C\& } \\
\hline & & & & Mean & SD & $\begin{array}{c}\begin{array}{c}\text { Confidence } \\
\text { interval }(95 \%)\end{array} \\
\end{array}$ \\
\hline \multicolumn{7}{|l|}{ Elymus L. } \\
\hline $\begin{array}{l}\text { E. abolinii (Drob.) Tzvelev } \\
\text { E. ciliaris (Trin.) Tzvelev } \\
\text { E. canadensis L. } \\
\text { E. caninus L. } \\
\text { E. caninus } \\
\text { E. glaucus (Buckley) } \\
\text { E. glaucus } \\
\text { E. lanceolatus (Schribner \& Sunith) Gould } \\
\text { E. lanceolatus } \\
\text { E. mutabilis (Drob.) Tzvelev } \\
\text { E. mutabilis } \\
\text { E. sibiricus L. } \\
\text { E. sibiricus } \\
\text { E. trachycaulus (Link) Gould ex Shinners } \\
\text { E. trachycaulus } \\
\text { E. trachycaulus } \\
\text { E. alatavicus (Drob.) À. Löve } \\
\text { E. dahuricus Turez ex Griseb. } \\
\text { E. dahuricus }\end{array}$ & $\begin{array}{l}\text { StStYY } \\
\text { StStYY } \\
\text { StStHH } \\
\text { StStHH } \\
\text { StStHH } \\
\text { StStHH } \\
\text { StStHH } \\
\text { StStHH } \\
\text { StStHH } \\
\text { StStHH } \\
\text { StStHH } \\
\text { StStHH } \\
\text { StStHH } \\
\text { StStHH } \\
\text { StStHH } \\
\text { StStHH } \\
\text { StStYYPP } \\
\text { StStHHYY } \\
\text { StStHHYY }\end{array}$ & $\begin{array}{l}28 \\
28 \\
28 \\
28 \\
28 \\
28 \\
28 \\
\\
28 \\
28 \\
28\end{array}$ & $\begin{array}{l}\text { PI } 531554 \\
\text { PI } 531576 \\
\text { PI } 531565 \\
\text { PI } 253290 \\
\text { PI } 439906 \\
\text { D3261 } \\
\text { D3268 } \\
\text { D3626 } \\
\text { D3627 } \\
\text { PI } 499449 \\
\text { PI } 499589 \\
\text { PI } 499613 \\
\text { PI } 499616 \\
\text { PI } 232168 \\
\text { PI } 276711 \\
\text { PI } 315368 \\
\text { PI } 499475 \\
\text { PI } 499592 \\
\text { PI } 499593\end{array}$ & $\begin{array}{l}\mathbf{1 8 . 7 0} \\
17.33 \\
21.11 \\
17.09 \\
\mathbf{1 7 . 1 2} \\
\mathbf{1 8 . 6 2} \\
\mathbf{1 8 . 3 3} \\
\mathbf{1 6 . 5 7} \\
\mathbf{1 6 . 8 5} \\
\mathbf{1 6 . 5 0} \\
\mathbf{1 7 . 4 2} \\
\mathbf{1 6 . 6 2} \\
\mathbf{1 6 . 5 9} \\
\mathbf{1 9 . 1 3} \\
\mathbf{1 7 . 4 8} \\
\mathbf{1 7 . 8 0} \\
\mathbf{3 0 . 3 1} \\
\mathbf{2 6 . 4 3} \\
\mathbf{2 5 . 1 6}\end{array}$ & $\begin{array}{l}0.30 \\
0.44 \\
1.01 \\
0.44 \\
0.17 \\
0.15 \\
0.50 \\
0.30 \\
0.18 \\
0.92 \\
0.42 \\
0.31 \\
0.25 \\
0.31 \\
0.65 \\
0.51 \\
1.07 \\
0.45 \\
0.37\end{array}$ & $\begin{array}{l}18.22-19.17 \\
16.63-18.02 \\
19.49-22.72 \\
16.39-17.80 \\
16.85-17.39 \\
18.38-18.86 \\
17.54-19.12 \\
16.09-17.05 \\
16.56-17.15 \\
15.03-17.97 \\
16.75-18.09 \\
16.13-17.12 \\
16.19-16.99 \\
18.63-19.62 \\
16.45-18.51 \\
16.99-18.62 \\
28.61-32.02 \\
25.72-27.14 \\
24.57-25.74\end{array}$ \\
\hline \multicolumn{7}{|l|}{ Leymus Hochst. } \\
\hline $\begin{array}{l}\text { L. akmolinensis (Drob.) Tzvelev } \\
\text { L. ambiguus (Vasey \& Schribn.) D.R. Dewey } \\
\text { L. chinensis (Trin.) Tzvelev } \\
\text { L. chinensis } \\
\text { L. flavens (Scribner \& Smith) Pilger } \\
\text { L. racemosus (Lam.) Tzvelev } \\
\text { L. racemosus } \\
\text { L. cf. racemosus } \\
\text { L. cf. ramosus (Trin.) Tzvelev } \\
\text { L. sabulosus (M. Bieb.) Tzvelev } \\
\text { L. sabulosus } \\
\text { L. secalinus (Georgi) Tzvelev } \\
\text { L. secalinus } \\
\text { L. triticoides (Buckl) Pilger } \\
\text { L. tritcoides } \\
\text { L. tritcoides } \\
\text { L. tritcoides }\end{array}$ & $\begin{array}{l}\text { NsNsXmXm } \\
\text { NsNsXmXmm } \\
\text { NsNsXmXmm } \\
\text { NsNsXmXmm } \\
\text { NsNsXmXmm } \\
\text { NsNsXmXm } \\
\text { NsNsXmXm } \\
\text { NsNsXmXm } \\
\text { NsNsXmXm } \\
\text { NsNsXmXm } \\
\text { NsNsXmXm } \\
\text { NsNsXmXm } \\
\text { NsNsXmXm } \\
\text { NsNsXmXm } \\
\text { NsNsXmXm } \\
\text { NsNsXmXm } \\
\text { NsNsXmXm }\end{array}$ & $\begin{array}{l}28 \\
28 \\
28 \\
28 \\
28 \\
28 \\
28 \\
28 \\
28 \\
28 \\
28 \\
28 \\
28 \\
28 \\
28 \\
28\end{array}$ & $\begin{array}{l}\text { PI 440306 } \\
\text { KJ59 } \\
\text { PI } 499515 \\
\text { PI } 499518 \\
\text { Has \& Har } \\
\text { PI 313965 } \\
\text { PI 531812 } \\
\text { DJ3801 } \\
\text { PI } 499654 \\
\text { PI } 531813 \\
\text { PI } 531814 \\
\text { PI } 499524 \\
\text { PI 499528 } \\
\text { PI 531822 } \\
\text { D2950 } \\
\text { Asay M-9 } \\
\text { cv. Shoshone }\end{array}$ & $\begin{array}{l}22.60 \\
22.27 \\
19.42 \\
19.70 \\
24.44 \\
21.93 \\
22.78 \\
21.16 \\
20.31 \\
22.98 \\
22.71 \\
21.36 \\
21.57 \\
22.41 \\
22.39 \\
21.61 \\
21.08\end{array}$ & $\begin{array}{l}0.25 \\
0.71 \\
0.16 \\
0.63 \\
0.48 \\
0.14 \\
0.40 \\
1.08 \\
0.20 \\
0.19 \\
0.09 \\
0.33 \\
0.16 \\
0.29 \\
0.95 \\
0.89 \\
0.25\end{array}$ & $\begin{array}{l}22.21-23.00 \\
21.13-23.40 \\
19.16-19.68 \\
18.70-20.69 \\
23.68-25.50 \\
21.70-22.16 \\
22.15-23.42 \\
19.44-22.88 \\
20.00-20.63 \\
22.68-23.28 \\
22.56-22.85 \\
20.83-21.89 \\
21.31-21.84 \\
21.94-22.87 \\
20.87-23.90 \\
20.19-23.04 \\
20.68-21.48\end{array}$ \\
\hline \multicolumn{7}{|l|}{ Pascopyrum À. Löve } \\
\hline $\begin{array}{l}\text { P. smithii (Rydb.) À. Löve } \\
P \text {. smithii } \\
P \text {. smithii }\end{array}$ & $\begin{array}{l}\text { StStHHNsNsXmXm } \\
\text { StStHHNsNsXmXm } \\
\text { StStHHNsNsXmXm }\end{array}$ & $\begin{array}{l}56 \\
56 \\
56\end{array}$ & $\begin{array}{l}\text { cv. Flintlock } \\
\text { cv. Barton } \\
\text { cv. Rodan }\end{array}$ & $\begin{array}{l}\mathbf{3 5 . 3 9} \\
\mathbf{3 3 . 5 3} \\
\mathbf{3 4 . 0 8} \\
\end{array}$ & $\begin{array}{l}0.88 \\
0.70 \\
0.46 \\
\end{array}$ & $\begin{array}{l}34.00-36.78 \\
32.41-34.65 \\
33.35-34.81 \\
\end{array}$ \\
\hline
\end{tabular}

$\uparrow$ Superscript on genome letters refers to a subset of that genome.

\$ PI numbers are accession numbers of the USDA Plant Germplasm system; other strain numbers are from the Triticeae collection at Logan, UT (K. Jensen). § Strain means and standard deviations (SD) based on four plants per accession; 1000 nuclei were scanned per plant.

et al., 1991). The recent development of methods to determine nuclear DNA content of plants by flow cytometry facilitates the determination of DNA content of a large number of plants (Galbraith et al., 1983; Rayburn et al., 1989; Michaelson et al., 1991; Arumuganathan and Earle, 1991). The purpose of this study was to use flow cytometry analyses to determine the base DNA content of the genomes of the perennial Triticeae. Diploid, autopolyploid, and allopolyploid species that are characteristic of the tribe were used to relate DNA content to previously reported genomic relationships.

\section{MATERIALS AND METHODS}

The grasses used in this study were primarily plant introductions obtained from the U.S. Department of Agriculture's National Plant Germplasm System via the USDA-ARS Forage and Range Research Laboratory at Utah State University, Logan, UT, (K. Jensen) where they were identified. Authorities for genera and species are listed with genus and species names in Table 1 . These accessions have a PI (for plant introduction) numerical designation and can be obtained from the USDA Plant Germplasm System. Chromosome numbers of these accessions were determined by the USDA-ARS Forage and Range Laboratory at Logan. The other strains used in this study are experimental breeding lines maintained by USDAARS Laboratory at Logan or were released cultivars (designated $\mathrm{cv}$.) obtained by the USDA-ARS grass breeding program at Lincoln, NE (K.Vogel). To simplify terminology, the cultivars, experimental breeding lines, and plant germplasm accessions will be referred to as strains in this report. The strains used in the study (Table 1) were chosen to represent the autoploid and alloploid combinations that exist within the perennial Triticeae. Many of the species were represented by two strains. Australopyrum species that have the $\mathrm{W}$ genome were not available for use in this study.

Plants were grown in a greenhouse of the USDA Forage Research Laboratory at Lincoln. The grasses were planted in super-cell cone-tainers (Steuwe and Sons, Corvallis, OR) or mini-pots in the greenhouse. A plot consisted of two rows with 7 cells per row for a total of 14 seedlings per strain. Four 
Table 2. Nuclear DNA content of the genomes of the perennial Triticae.

\begin{tabular}{|c|c|c|c|c|c|c|c|}
\hline \multirow[b]{3}{*}{ Species } & \multirow[b]{3}{*}{ Basic genome } & \multirow[b]{3}{*}{$2 n$} & \multirow{2}{*}{\multicolumn{2}{|c|}{ DNA pg/2C }} & \multirow{3}{*}{$\begin{array}{c}\text { Confidence } \\
\text { interval§ }\end{array}$} & \multicolumn{2}{|c|}{ Estimated DNA content } \\
\hline & & & & & & \multirow[b]{2}{*}{ MeanII } & \multirow{2}{*}{$\begin{array}{c}\text { Confidence } \\
\text { interval }\end{array}$} \\
\hline & & & Mean $\dagger$ & $\mathbf{S D} \ddagger$ & & & \\
\hline Agropyron & $\mathbf{P P}$ & 14 & 13.93 & 1.08 & $12.46-14.46$ & & \\
\hline Pseudoroegeneria & StSt & 14 & 8.75 & 0.71 & $8.22-9.28$ & & \\
\hline Hordeum & HH & 14 & 9.48 & 0.47 & $9.21-9.75$ & & \\
\hline Psathyrostachys & NsNs & 14 & 16.73 & 1.16 & $15.29-18.18$ & & \\
\hline \multirow[t]{3}{*}{ Thinopyrum } & $\mathbf{E}^{b} \mathbf{E}^{b}$ & 14 & 14.91 & 0.07 & 14.29-15.54 & & \\
\hline & $\mathbf{E}^{e} \mathbf{E}^{e}$ & 14 & 11.97 & $\mathbf{0 . 3 3}$ & 9.05-14.89 & & \\
\hline & EEEE & 28 & 24.80 & $1.66 t+$ & $9.93-39.66$ & 26.88 & 22.61-31.15 \\
\hline T. caespitosum & EEStSt & 28 & $19.83 \neq \neq$ & $1.12+t+$ & 18.09-21.67 & 20.72 & $18.46-22.98$ \\
\hline T. intermedium & EEEEStSt & 42 & 26.08 & $0.23+\dagger$ & 24.05-28.11 & 31.80 & 30.08-33.58 \\
\hline T. ponticum & EEEEEEStStStSt & 70 & 45.26 丰 & $1.49+t+$ & $42.89-47.64$ & 45.91 & $44.24-47.58$ \\
\hline & StStYY & 28 & 18.01 & 0.97 & $9.37-26.65$ & & \\
\hline \multirow{4}{*}{$\begin{array}{l}\text { Elymus } \\
\text { (calculated) }\end{array}$} & YY & 14 & 9.26 & & & & \\
\hline & StStHH & 28 & 17.66 & 1.29 & $16.90-18.42$ & 18.23 & $17.40-19.06$ \\
\hline & StStYYPP & 42 & $\mathbf{3 0 . 3 1}$ & 1.07 & $28.61-32.02$ & 31.94 & $29.94-33.94$ \\
\hline & StStHHYY & 42 & 25.79 & 0.90 & 17.71-33.87 & 27.49 & $24.22-30.76$ \\
\hline Leymus & NsNsXmXm & 28 & 21.81 & 1.26 & & & \\
\hline (calculated) & $\mathbf{X m X m}$ & 14 & 2.7 to 7.7 & & & & \\
\hline Pascopyrum & StStHHNsNsXmXm & 56 & 34.33 & 0.96 & $31.97-36.70$ & 39.47 & 38.95-39.99 \\
\hline
\end{tabular}

† Means of species with same genomes in Table 1.

\$ Standard deviation (SD) of means of species with same genomes in Table 1 .

$\S$ Confidence interval $(95 \%)$ of mean of species with same genomes.

II Estimated mean obtained by summing mean values of constituent genomes of probable diploid or polyploid progenitors.

\# Estimated confidence intervals obtained by using variances of estimated means. Variance of estimated means obtained by summing variances of constituent genomes.

$\dagger \dagger$ DNA content of strains with same genomes differed significantly resulting in large SD and confidence interval.

\$ Standard deviation of plants from the single accession with this genome configuration.

seedlings of each strain were sampled as individuals. One seedling was sampled twice with "a" or "b" added to the plant number. By taking two samples from the same seedling, the laboratory standard error for the flow cytometry procedure was determined.

Flow cytometry procedures were those of Arumuganathan and Earle (1991). Approximately $50 \mathrm{mg}$ of fresh, green tissue from a collared leaf of a Triticeae seedling was excised and placed on ice in a sterile 35 - by $10-\mathrm{mm}$ plastic petri dish. About $20 \mathrm{mg}$ of barley (Hordeum vulgare L. cv. Stark) or hexaploid wheat (Triticium aestivum L. cv. Chinese Spring or cv. Arapahoe) leaf tissue from seedling leaves was added as a standard. The tissue was chopped into $0.25-$ to $1.0-\mathrm{mm}$ segments in $1 \mathrm{~mL}$ of solution A [24 mL $\mathrm{MgSO}_{4}$ buffer (ice-cold); $25 \mathrm{mg}$ dithiothreitol; $500 \mu \mathrm{L}$ propidium iodide stock $(5.0 \mathrm{mg}$ propidium iodide in $1.0 \mathrm{~mL}$ double distilled $\mathrm{H}_{2} \mathrm{O}$ ); $625 \mu \mathrm{L}$ Triton

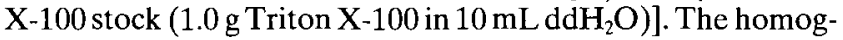
enate was filtered through a $30-\mu \mathrm{m}$ nylon mesh into a microcentrifuge tube and centrifuged at high speed (13000 RPM) for $20 \mathrm{~s}$. The supernatant was discarded, the pellet was resuspended in $400 \mu \mathrm{L}$ of solution $\mathrm{B}[7.5 \mathrm{~mL}$ solution $\mathrm{A} ; 17.5 \mu \mathrm{L}$ RNAse (DNAse free)] and incubated for $15 \mathrm{~min}$ at $37^{\circ} \mathrm{C}$ before flow cytometric analyses.

The prepared material was analyzed in the University of Nebraska Flow Cytometry Core Research Facilities on a standard FACScan flow cytometer (Becton Dickinson Immunocytometry System, San Jose, CA). For each measurement, propidium iodide fluorescence area signals (FL2-A) from 1000 nuclei were collected by CellQuest software (Becton Dickinson Immunocytometry System, San Jose, CA). A live gate was set with the FL2-2 and FSC parameters allowing the fluorescence measurement from nuclei to generate a histogram of FL2-A. Mean position of G0/G1 (nuclei) peak of the sample and internal standard were determined by analyzing the data by CellQuest software. The mean DNA content per plant was based on the 1000 scanned nuclei. The standards used for comparison were Stark diploid barley $(10.68 \mathrm{pg} / 2 \mathrm{C})$ or hexaploid wheats $(34.68 \mathrm{pg} / 2 \mathrm{C})$ for which the DNA content was known. Both barley and wheat were used as standards because of the large range in DNA content of the strains analyzed. The DNA content of Stark barley was determined with chicken erythrocytes (2.33 pg/2C; Galbraith et al., 1993) as the standard. Chinese Spring and Arapahoe wheat had the same nuclear DNA content (34.68 pg/2C) as determined with Stark barley as the standard. The nuclear DNA content of the hexaploid wheats used in this study as standards is equivalent to the DNA content $(34.63 \mathrm{pg} / 2 \mathrm{C})$ listed for Chinese Spring by Bennett and Leitch (1995). Because of the large number of plants analyzed in this study, numerous trays of the standards had to be planted. Arapahoe is a widely grown winter wheat and seed is more readily available than seed of Chinese Spring. The formula used for converting fluorescence values to DNA content was:

\section{Nuclear DNA content $=$ (mean position of unknown peak $) /($ mean position of known) $\times$ DNA content of known standard.}

In Table 1, the strain or accession means are based on the four seedlings analyzed per strain. In Table 2 , the means are based on the means of accessions with the same base genome. Autotetraploid mean values were divided by 2 to obtain a mean diploid value for calculating the mean genome values in Table 2. A simple statistical procedure using confidence intervals was used to compare mean DNA content of the strains (Steel and Torrie, 1960). A confidence interval was calculated for each mean by the following equation:

$$
P\left(\overline{\mathrm{x}}_{1}-t_{0.05} s_{\overline{\mathrm{x}}}<\mu<\overline{\mathrm{x}}_{1}+t_{0.05} S_{\overline{\mathrm{x}}}\right)=0.95,
$$

where $t_{0.05}$ is the " $t$ " statistic and $s_{x}=s / n^{1 / 2}$ where $n$ is the number of plants analyzed for a strain and $s$ is their standard deviation. Accession means with overlapping confidence intervals were assumed to be similar. This is equivalent to conducting a simple $t$ test to compare specific means (Steel and Torrie, 1960).

Estimated DNA content of the allopolyploid genera was determined by summing the means of the two probable con- 
stituent diploid or polyploid progenitors. For example, the estimated mean DNA content of Pascopyrum (StStHHNs Ns XmXm) was obtained by summing the mean DNA content values for Elymus (StStHH) and Leymus (NsNsXmXm) as per Dewey (1975). The variance of the estimated mean DNA content, which was calculated by summing the variances of the constituent genomes, was used to calculate a confidence interval for each estimated mean (Snedecor and Cochran, 1967).

\section{RESULTS}

The standard error of difference of the duplicate samples analyzed for each strain was $0.04 \mathrm{pg} / \mathrm{nucleus}$ indicating a high degree of precision for the flow cytometry procedure used in this study. In addition, low standard deviation values were obtained for each of the accessions analyzed (Table 1). Flow cytometry results for Hordeum bulbosum, both diploid and tetraploid, are smaller than those reported previously by Bennett and Smith (1976) but are larger than the previous report for Thinopyrum elongatum (Table 1). Our flow cytometry results are based on different strains and on a larger number of cells.

\section{Agropyron}

In the classification system of Barkworth and Dewey (1985), the genus Agropyron is restricted to the group of species with the $\mathrm{P}$ genome known as the crested wheatgrasses. Agropyron contains about 10 species and includes diploids, autotetraploids, and autohexaploids. We did not analyze the hexaploids in this study. Among the diploid Agropyron species, there are significant differences in DNA content. The DNA content of the $A$. cristatum strains as typified by the cultivar Ruff and PI 297870 is less than the DNA content of the A. mongolicum strains (Table 1). Hsiaso et al. (1986) indicated that the genome length of $A$. cristatum based on measurement of chromosome lengths was slightly shorter than that of $A$. mongolicum. One $A$. cristatum strain, PI 314600 , was intermediate in DNA content between the A. mongolicum strains and the cultivar Ruff. The DNA content of the two tetraploid Agropyron strains, PI 249143 and the cultivar Nordan, suggest that they are based on the smaller P genome typified by the cultivar Ruff. If they were based on the larger P genomes, the expected DNA content value per nuclei would exceed the confidence interval obtained for the tetraploid Agropyron species(Table 1). Satellite or B chromosomes have been reported in Agropyron (McCoy and Law, 1965). Small differences in DNA content within Agropyron species may be due to the presence or absence of satellite chromosomes, but the large differences in genome size between $A$. cristatum and $A$. mongolicum exceeds the probable DNA content of satellite chromosomes since the average DNA content of an Agropyron chromosome is about $1 \mathrm{pg}$.

\section{Pseudoroegneria}

Pseudoroegneria is based on the St genome and contains about 15 species, but only one, $P$. spicata, is native to North America (Dewey and Barkworth 1985). The genus contains diploid and autotetraploid species (Table 1). The DNA content of $P$. libanotica and $P$. stipifolia accessions was significantly smaller than the DNA content of $P$. aegilopoides, $P$. strigosa, and one of the $P$. spicata strains (PI 232127). The other $P$. spicata strain (PI 232134) was intermediate in DNA content to the previously described small and large St genomes. On the basis of DNA content and the $95 \%$ confidence interval range for the autotetraploid $P$. geniculata strains, it appears that this autotetraploid species contains a small and a large St genome.

\section{Hordeum}

The perennial species in the genus Hordeum are based on the $\mathrm{H}$ genome (Dewey, 1984). The nuclear DNA content of diploid species of this genus also varied significantly ranging from $8.9 \mathrm{pg} \mathrm{DNA} / 2 \mathrm{C}$ for $H$. flexuosum and $H$. haplophilum to $10.0 \mathrm{pg} \mathrm{DNA} / 2 \mathrm{C}$ for the two strains of $H$. stenostachys (Table 1). Only one autotetraploid, a $H$. bulbosum strain (PI 343189), was analyzed. Its DNA content was consistent with the expected DNA content considering the mean DNA content and confidence interval of the diploid H. bulbosum strain (PI 318649 ). The $\mathrm{H}$ genome is one of constituent genomes of many of the Elymus species.

\section{Psathyrostachys}

Psathyrostachys contains about 10 diploid species (Barkworth and Dewey, 1985) and they all have the Ns genome. The Psthyrostachys strains analyzed in this study had the largest DNA contents of the diploid species analyzed in this study (Tables 1 and 2). Diploid Russian wildrye ( $P$. juncea), which is used extensively as a pasture and rangeland grass in the Northern Plains of the USA and Canada, had significantly smaller DNA content than the DNA content of $P$. fragilis and $P$. stoloniformis. The Ns genome is one of the base genomes of the Leymus species. Since DNA content variation exists among the diploid Psathyrostachys species, it would be expected that variation in DNA content would exist among Leymus species.

\section{Thinopyrum}

Thinopyrum contains diploid, autotetraploid, and allotetraploid species and is based on the $\mathrm{E}$ (formerly $\mathrm{J}$ ) and St genomes. It has recently been demonstrated that there are two forms of the $\mathrm{E}$ genome, $\mathrm{E}^{\mathrm{b}}$ and $\mathrm{E}^{\mathrm{e}}$, as indicated by a genome specific RAPD (random amplified polymorphic DNA) marker (Zhang and Wang, 1996). The polyploid species that contain the $E$ genome may have one or both genome types (Zhang and Wang,1996; Zhang et al., 1996). The diploid $E^{b} E^{b}$ genome as typified by two $T$. bessarabicum strains had $14.9 \mathrm{pg}$ DNA/2C (Tables 1 and 2). The diploid $\mathrm{E}^{\mathrm{e}} \mathrm{E}^{\mathrm{e}}$ genome as typified by $T$. elongatum had $12.0 \mathrm{pg}$ DNA/ $2 \mathrm{C}$. The $\mathrm{E}^{\mathrm{b}}$ and $\mathrm{E}^{\mathrm{e}}$ genomes differed significantly in DNA content (Table 1). Thinopyrum junceiforme is an allotetraploid based on the $E$ genome. The two strains 
of $T$. junceiforme analyzed differed significantly in DNA content (Table 1). Our results indicate that $T$. junceiforme strain $\mathrm{D} 3463$ may have an $\mathrm{E}^{e} \mathrm{E}^{e} \mathrm{E}^{e} \mathrm{E}^{e}$ genomic constitution but that $T$. junceiforme strain PI 297873 probably has an $E^{e} E^{e} E^{b} E^{b}$ genomic constitution. Because the two stains of $T$. junceiforme differed in size, the $95 \%$ confidence interval for the genomic combination EEEE is large (Table 2). The expected DNA content/nuclei of a plant with the genomic configuration EEEE based on a summation of the DNA content of the base genomes lies within this confidence interval.

Thinopyrum caespitosum is an allotetraploid that contains the E and St genomes (Liu and Wang, 1993). The expected DNA content/nuclei of a plant with the genomic configuration EEStSt, based on a summation of the DNA content of the base genomes, lies within the confidence interval for DNA content measurements made on $T$. caespitosum plants (Table 2). On the basis of DNA content size, $T$. caespitosum probably contains the $\mathrm{E}^{\mathrm{e}}$ genome. The intermediate wheatgrass cultivars that were analyzed typify the two types of intermediate wheatgrass (Table 1). The cultivar Slate (Thinopyrum intermedium subsp. intermedium) represents the "Intermediate" wheatgrass type; the cultivar Manska (Thinopyrum intermedium subsp. barbulatum) represents the "Pubescent" wheatgrass type. The DNA content/nuclei of the two cultivars are similar (Table 1). Genomespecific RAPD markers were recently used to determine genome components of $T$. intermedium and $T$. ponticum species (Zhang and Wang,1996; Zhang et al., 1996). Their results indicate that $T$. intermedium had $\mathrm{E}^{\mathrm{b}}$ and/ or $\mathrm{E}^{\mathrm{e}}$ and $\mathrm{St}$ genomes in its allohexaploid genome, whereas $T$. ponticum had three $\mathrm{E}$ genomes (probably 2 $\mathrm{E}^{\mathrm{b}}$ and $1 \mathrm{E}^{\mathrm{e}}$ ) and two St genomes in its haplome. If the assumption is made that $T$. intermedium developed by the hybridization of plants with the $E^{e} E^{e}$ and $E^{e} E^{e} S t S t$ genomes with subsequent doubling of the chromosomes of the hybrid $F_{1}$ plants, the expected DNA content/ nuclei of an intermediate wheatgrass plant with the genomic configuration $\mathrm{E}^{e} \mathrm{E}^{e} \mathrm{E}^{e} \mathrm{E}^{e} \mathrm{StSt}$ is $31.8 \mathrm{pg} / 2 \mathrm{C}$, which is larger than the upper limit of $95 \%$ confidence interval for the measured DNA content of the intermediate wheatgrasses (Table 2). Assuming hybridization of plants with the EEStSt and EEEEStSt genomes, the estimated mean DNA content for $T$. ponticum, which has the EEEEEEStStStSt genomic configuration, is $45.91 \mathrm{pg}$, which is within the $95 \%$ confidence interval of the measured DNA content.

\section{Elymus}

The genus Elymus contains allopolyploid species that have the StStYY, StStYYPP, StStHH, and StSt genomic configuration. The diploid origin of the $\mathrm{Y}$ genome is unknown (Dewey, 1984). The two species that have the StStYY tetraploid configuration, E. abolinii and $E$. ciliaris, differed in mean nuclear DNA content (Table 1). The difference in nuclear DNA content between these two species could be due to differences in size of the constituent St or Y genome size. The estimated size of the YY diploid genome, as determined by difference, was approximately $9.3 \mathrm{pg} / 2 \mathrm{C}$. The nuclei DNA content of E. alatavicus (StStYYPP) was $30.3 \mathrm{pg} /$ nucleus (Table
1). The expected DNA content/nuclei of a plant with the same genomic configuration based on a summation of the DNA content of the base genomes StStYY and PP lies within the $95 \%$ confidence interval for E. alatavicus (Table 2). Several species of Elymus have the genomic configuration StStHH including E. canadensis and $E$. lanceolatus. The genomes of these two species differ significantly in DNA content (Table 1). Gabraith et al. (1983) used flow cytometry to determine nuclear DNA content of an array of species. They reported that $E$. canadensis had $21.6 \mathrm{pg} / 2 \mathrm{C}$ DNA which is equivalent to the value obtained in this study. There also is variation in DNA content among the other Elymus species with the allotetraploid configuration StStHH. Variation in DNA content among these species would be expected since variation in DNA content was found among species of their diploid progenitors. On the basis of component genomes (Table 2), the mean DNA content/nuclei of some Elymus species with the StStHH genomic configuration were outside the confidence interval range for all species with this genomic configuration and outside the estimated confidence interval range.

\section{Leymus}

Leymus species are allotetraploids that have the NsNsXmXm genomic configuration. The Xm genome previously was believed to be the $J(=E)$ genome (Dewey, 1984) but as indicated previously Zhang and Dvorak (1991) and Wang and Jensen (1994) using molecular and cytogenetic analyses, respectively, determined that the E genome is not found in Leymus. The diploid $\mathrm{XmXm}$ genome has an estimated DNA content of 2.7 to $7.7 \mathrm{pg} / 2 \mathrm{C}$ (Table 2) which would make it significantly smaller than the diploid $\mathrm{E}^{\mathrm{e}} \mathrm{E}^{\mathrm{e}}$ genome which has an average of $12.0 \mathrm{pg} / 2 \mathrm{C}$. The results of this study strongly support the research that indicates that the $\mathrm{E}$ genome is not found in Leymus. There are significant differences in DNA content among the Leymus species (Table 1).

\section{Pascopyrum}

Pascopyrum contains a single species, Pascopyrum smithii or western wheatgrass, and is believed to have originated as the product of hybridization between beardless wildrye, Leymus triticoides (Buckl.) and thickspike wheatgrass (Elymus lanceolatus) or closely related species (Dewey, 1984). The expected DNA content of a western wheatgrass plant produced by the hybridization of plants with the genomic configuration described by Dewey (1975) is $39.47 \mathrm{pg} / 2 \mathrm{C}$, which is larger than the upper limit of the $95 \%$ confidence interval for the DNA content of the three western wheatgrass strains analyzed in this study (Table 2 ).

This report presents the first information on DNA content for most of the species that were evaluated. In a previous report, Hsiao et al. (1986) determined relative genome size of diploid species reprenting the $\mathrm{P}, \mathrm{E}^{\mathrm{e}}$, $\mathrm{E}^{\mathrm{b}}$, St, Ns, and $\mathrm{H}$ genomes by summing the length of chromosomes for each species. Thirteen species evaluated by Hsiao et al. (1986) were included in this study. The correlation between genome size as determined by 
genome length (micrometers) and DNA content (pg/ $2 \mathrm{C}$ ) was $r=0.84$ (significant at the $95 \%$ level of probability).

\section{DISCUSSION}

DNA content of diploid species of plants can change via an array of genetic processes including deletion or insertion of chromosomal fragments during meiosis (Schultz-Shafer, 1980). Changes in DNA content also can be due to differences in repeated DNA sequences. Alteration in DNA content and the resulting change in gene expression is part of the speciation process. Our results indicate that genomes of the perennial Triticeae differ significantly in DNA content as measured by flow cytometry. DNA content also varies among the diploid species within each of the following genera: Agropryon, Pseudoroegneria, Hordeum,Psathyrostachys, and Thinopyrum. These genera are defined on the genomic system of classification which uses the degree of normal pairing of homologous chromosomes of interspecific and intergeneric hybrids during meiosis as a primary classification criterion. Our results indicate that related subsets of genomes can vary in size as measured by DNA content and on the basis of previous research that was extensively reviewed by Dewey (1984) still have homologous chromosome pairing during meiosis in interspecific and intergenomic hybrids. The processes that enable this to occur are not known. In Agropyron, Pseudoroegneria, Hordeum, Psathyrostachys, and Thinopyrum, genomic mapping studies will be needed to explain the genetic basis for the differences in genome size within the $\mathrm{P}, \mathrm{St}, \mathrm{H}, \mathrm{Ns}$, and $\mathrm{E}$ genomes.

Since significant differences in genome size were found to exist among and within the base genomes of the perennial Triticeae as determined by analysis of diploid species, it is not surprising that significant differences were found among auto- and allopolyploids that have the same genomic configuration in Thinopyrum, Elymus, and Leymus. The DNA content of the alloploid species, T. intermedium and Pascopyrum smithii, was significantly smaller than expected on the basis of DNA content of their constituent genomes. These results clearly indicate that DNA was lost, probably as chromosome fragments, in the evolutionary development of these allohexaploid wheatgrasses from their diploid progenitors. In summary, our results clearly demonstrate that gain or loss of nuclear DNA occurred during the evolution of the perennial Triticeae and was a part of the species development process.

\section{ACKNOWLEDGMENTS}

The authors thank Steve Masterson, Jennifer Bernard, and Maria Wyar for their diligent work in tissue preparation for this study.

\section{REFERENCES}

Arumuganathan, K., and E.D. Earle. 1991. Estimation of nuclear DNA contents of plants by flow cytometry. Plant Mol. Biol. Rep. 9:229-241.
Asay, K.H., and J.B. Jensen. 1996a. Wheatgrasses. p. 691-724. In L.E. Moser et al. (ed.) Cool-season forage grasses. Agron. Monogr. 34 ASA, CSSA, and SSSA, Madison, WI.

Asay, K.H., and J.B. Jensen. 1996b. Wildryes. p. 725-748. In L.E. Moser et al. (ed.) Cool-season forage grasses. Agron. Monogr. 34. ASA, CSSA, and SSSA, Madison, WI.

Barkworth, M.E. 1992 Taxonomy of the Triticeae: A historical perspective. Hereditas. 116:1-14.

Barkworth, M.E., and D.R. Dewey. 1985. Genomically based genera in the perennial Triticeae of North America: Identification and membership. Am. J. Bot. 72:767-776.

Bennett, M D., and I.J. Leitch. 1995. Nuclear DNA amounts in angiosperms. Ann. Bot. (London) 76:113-176.

Bennett, M.D., and J.B. Smith. 1976. Nuclear DNA amounts in angiosperms. Phil. Trans. R. Soc. Lond. B. 274:227-276.

Bennett, M.D., and J.B. Smith. 1991. Nuclear DNA amounts in angiosperms. Phil. Trans. Roy. Soc. of Lond. B. 334:309-345.

Dewey, D.R. 1975. The origin of Agropyron smitthii. Am. J. Bot. 62:524-530.

Dewey, D.R. 1984. The genomic system of classification as a guide to intergeneric hybridization with the perennial Triticeae. p. 209279. In J.P. Gustafson (ed.) Gene manipulation in plant improvement. 16th Stadler Genetics Symposium, Columbia, MO. Plenum Press, New York.

Galbraith, D.W., K.R. Harkins, J.M. Maddox, N.M. Ayres, P. Sharma, and E. Firoozabady. 1983. Rapid flow cytometric analysis of the cell cycle in intact plant tissue. Science 220:1049-1051.

Hsiao, C., R.R.-C. Wang, and D.R. Dewey. 1986. Karyotype analyses and genome relationships of 22 diploid species in the tribe Triticeae. Can. J. Genet. Cytol. 28:109-120.

Kellogg, E.A.1994. Systematics of the Triticeae: Problems and progress. p. 207-214. In R.R.C. Wang et al. (ed.) Proc. Int. Triticeae Symp., 2nd, Logan, UT. 20-24 June 1994. Utah State University, Logan.

Liu, Z-W., and R.R-C. Wang. 1993. Genome analyses of Elytriga caespitosa, Lopopyrum nodosum, Pseudoroegneria geniculata ssp. scythica, and Thinopyrum intermedium. Genome 36:102-111.

McCoy, G.A., and A.G. Law. 1965. Satellite chromosomes in crested wheatgrass (Agropyron desterorum (Fisch) Shult.) Crop Sci. 5:283.

Michaelson, M.J., H.J. Price, J.R. Ellison, and J.S. Johnston. 1991. Comparison of plant DNA contents determined by Feulgen microspectrophotometry and laser flow cytometry. Am. J. Bot. 78: 183-188.

Rayburn, A.L., J.A. Auger, E.A. Benzinger, and A.G. Hepburn. 1989. Detection of intraspecific DNA content variation in Zea mays $\mathrm{L}$. by flow cytometry. J. Exp. Bot. 40:1179-1183.

Schultz-Shaffer, J. 1980. Cytogenetics, plants, animals, humans. Springer-Verlag. New York.

Snedecor, G.W., and W.C. Cochran. 1967. Statistical methods. 6th ed. The Iowa State University Press. Ames.

Steel, R.G.D., and J.H. Torrie. 1960. Principles and procedures of statistics. McGraw-Hill, New York.

Wang, R.R-C., and K.B. Jensen. 1994. Absence of the J genome in Leymus species (Poaceae:Triticeae): Evidence from DNA hybridization and meiotic pairing. Genome. 37:231:235.

Wang, R.R-C., R. Von Bothmer, J. Dvorak, G. Fedak, I. LindeLaursen, and M. Muramatsu. 1994. p. 29-34. In R.R-C. Wang et al. (ed.) Proc. Int. Triticeae Symp., 2nd, Logan, UT. 20-24 June 1994. Utah State University, Logan.

Zhang, H-B., and J. Dvorak. 1991. The genome origins of tetraploid species of Leymus (Poaceae:Triticeae) inferred for variation in repeated nucleotide sequences. Am. J. Bot. 78:871-884.

Zhang, W.-Y., and R.R-C. Wang. 1996. Genome constitutions of Thinopyrum species determined by RAPD markers and GISH. p. 161-162. In Agronomy abstracts. ASA, Madison, WI.

Zhang, X., Y. Dong, R.R-C. Wang. 1996. Characteristics of genomes and chromosomes in partial amphiploids of the hybrid Triticum aestivum $\times$ Thinopyrum ponticum by in situ hybridization, isozyme analyses, and RAPD. Genome 39:1062-1071. 